\title{
ANALISA RASIO KEUANGAN UNTUK MEMPREDIKSI PERUBAHAN LABA PADA PERUSAHAAN TELEKOMUNIKASI INDONESIA
}

\author{
Engelwati Gani; Almitra Indira \\ Jurusan Akuntansi, Fakultas Ekonomi dan Bisnis, Universitas Bina Nusantara \\ J1. K.H. Syahdan No. 9, Palmerah, Jakarta Barat 11480
}

\begin{abstract}
This study was conducted to test the variable Current Ratio (CR), Net Profit Margin (NPM), Operating Margin Ratio (OMR), Return On Equity (ROE), Return on Assets (ROA) and Total Asset Turn Over (tattoo) to changing profit. Data obtained by the method of purposive sampling criteria (1) Telecommunications Companies listed on the Indonesia Stock Exchange (IDX) and consistently throughout the study period (2003 to 2010) and Telecommunication Company that provides the data of financial statements during the study period (2003 to 2010). The analysis showed that the data used in this study have been normally distributed and satisfy the classical assumptions, which include: there is no autocorrelation, no symptoms of multicollinearity, and no symptoms hetereskedasitas. From the results of regression analysis showed that the variables Net Profit Margin (NPM) and Operating Margin Ratio (OMR) partially significant effect on change in earnings. While the variable Current Ratio (CR), Return on Equity (ROE), Return on Assets (ROA) and Total Asset Turn Over (TATTOO) no significant effect on changes in earnings. The six variables used in the study jointly affect changes in earnings. Predictive capability of the six variables simultaneously is equal to $36.4 \%$.
\end{abstract}

Keywords: financial ratios, and changes in earnings

\begin{abstract}
ABSTRAK
Penelitian ini dilakukan untuk menguji variabel Current Ratio (CR), Net Profit Margin (NPM), Operating Margin Ratio (OMR), Return On Equity (ROE), Return on Asset (ROA) dan Total Asset Turn Over (TATO) terhadap perubahan laba. Data diperoleh dengan metode purposive sampling dengan kriteria (1) Perusahaan Telekomunikasi yang terdaftar di Bursa Efek Indonesia (BEI) dan konsisten ada selama periode penelitian (2003 sampai dengan 2010). Dan (2) Perusahaan Telekomunikasi yang menyediakan data laporan keuangan selama periode penelitian (2003 sampai dengan 2010). Hasil analisis menunjukkan bahwa data-data yang digunakan di dalam penelitian ini telah terdistribusi normal dan memenuhi asumsi klasik, yang meliputi : tidak terdapat autokorelasi, tidak terjadi gejala multikolinearitas, dan tidak terjadi gejala hetereskedasitas. Dari hasil analisa regresi menunjukkan bahwa variabel Net Profit Margin (NPM) dan Operating Margin Ratio $(O M R)$ secara parsial berpengaruh signifikan terhadap perubahan laba. Sedangkan variabel Current Ratio (CR), Return On Equity (ROE), Return On Asset (ROA) dan Total Asset Turn Over (TATO) tidak berpengaruh signifikan terhadap perubahan laba. Keenam variabel yang digunakan dalam penelitian ini secara bersamasama berpengaruh terhadap perubahan laba. Kemampuan prediksi dari keenam variabel secara simultan adalah sebesar $36,4 \%$.
\end{abstract}

Kata kunci: rasio keuangan, dan perubahan laba 


\section{PENDAHULUAN}

Sumber informasi akuntansi dari suatu perusahaan yang sangat penting adalah laporan keuangan. Standar Akuntansi Standar (SAK) No. 1 (IAI, 2009) menyatakan bahwa tujuan laporan keuangan adalah memberikan informasi posisi keuangan, kinerja, dan arus kas perusahaan. Informasi tersebut bermanfaat untuk pembuatan keputusan ekonomi serta sebagai alat pertanggungjawaban manajemen.

Dengan analisa rasio keuangan diharapkan dapat dijelaskan fenomena-fenomena yang terus berkembang. Perkembangan akuntansi mendorong dilakukannya beberapa studi yang meneliti kegunaan rasio keuangan secara objektif. Beberapa studi yang telah dilakukan adalah manfaat rasio keuangan dalam memprediksi perubahan laba pada perusahaan manufaktur oleh Juliana \& Sulardi (2003), analisis rasio keuangan dalam memprediksi perubahan laba pada bank-bank di Indonesia oleh Usman (2003), rasio keuangan dan prediksi pertumbuhan laba pada perusahaan manufaktur di BEJ oleh Ediningsih (2004), kemampuan rasio keuangan dalam memprediksi perubahan laba oleh Purnawati (2005), rasio keuangan yang paling baik untuk memprediksi pertumbuhan laba pada perusahaan manufaktur yang terdaftar di BEJ oleh Meythi (2005) dan analisis rasio keuangan untuk memprediksi pertumbuhan laba oleh Hapsari (2007).

Simpulan yang diperoleh dari beberapa penelitian menunjukkan hasil yang berbeda. Beberapa di antaranya bahkan kontradiktif terhadap yang lainnya. Oleh karena itu, penelitian ini dimaksudkan untuk melakukan pengujian lebih lanjut temuan-temuan empiris mengenai rasio keuangan, terutama yang berkaitan dengan kegunaannya untuk memprediksi pertumbuhan laba di masa yang akan datang.

Perusahaan telekomunikasi dipilih sebagai sampel penelitian didasari oleh alasan bahwa pada era serba connected, setiap orang ingin selalu terhubung dengan dunia luar, komunikasi tidak hanya digunakan oleh kalangan pebisnis untuk menjalankan kegiatan perusahannya, tetapi juga sudah menjadi kebutuhan sehari-hari yang mencakup semua kalangan. Dilihat dari pertumbuhan perusahaan telekomunikasi yang terdaftar di Bursa Efek Indonesia, tercatat sebelum tahun 2009 hanya ada lima perusahaan telekomunikasi, tetapi pada awal tahun 2011, tercatat ada sembilan perusahaan telekomunikasi. Didasarkan pada kenyataan tersebut, perusahaan telekomunikasi dianggap akan terus bertahan dan mungkin akan bertambah seiring dengan kebutuhan berkomunikasi yang semakin meningkat.

\section{METODE}

Karakteristik riset ini adalah: (1) jenis riset pengujian hipotesis dengan jenis riset kausal; (2) metode penelitian kuantitatif; (3) jenis data sekunder; (4) dimensi waktu melibatkan urutan waktu dan banyak sampel; (5) metode pengumpulan data dengan observasi, data arsip, dan analitikal; (6) lingkungan penelitian noncontived setting,yaitu lingkungan riil; dan (7) unit analisanya beberapa perusahaan telekomunikasi yang terdaftar di BEI.

Dalam penyusunannya, hipotesis tidak terjadi begitu saja, hipotesis perlu dikembangkan dengan menggunakan teori yang relevan atau dengan logika hasil-hasil penelitian sebelumnya.

Berikut adalah pengembangan hipotesis dari penelitian ini.

\section{Prediksi Perubahan Current Ratio (CR) terhadap Laba}

Rasio ini sering disebut dengan rasio modal kerja yang menunjukkan jumlah aktiva lancar yang tersedia yang dimiliki oleh perusahaan untuk merespon kebutuhan-kebutuhan bisnis dan meneruskan kegiatan bisnis hariannya. Rasio yang rendah menunjukkan likuiditas yang tinggi. 
Pengaruh current ratio terhadap perubahan laba adalah semakin tinggi nilai current ratio maka laba bersih yang dihasilkan perusahaan semakin sedikit, karena rasio lancar yang tinggi menunjukkan adanya kelebihan aktiva lancar yang tidak baik terhadap profitabilitas perusahaan karena aktiva lancar menghasilkan return yang lebih rendah dibandingkan dengan aktiva tetap (Hanafi \& Halim, 2003).

Dalam penelitian sebelumnya ada beberapa peneliti yang menggunakan current ratio untuk memprediksi perubahan laba yang akan datang, yaitu Juliana \& Sulardi (2003) menggunakan current ratio untuk memprediksi perubahan laba pada perusahaan manufaktur yang terdaftar di BEJ dengan periode penelitian 1998-2000. Hasil penelitian menunjukkan bahwa current ratio tidak mempunyai kemampuan signifikan dalam memprediksi laba tetapi mempunyai hubungan yang positif dengan perubahan laba.

Purnawati (2005) menggunakan current ratio untuk memprediksi laba pada perusahaan agriculture, forestry and fishing; animal feed and husbandary; mining and mining services; construction and manufacture yang terdapat di BEJ dan ICMD selama periode 2000-2003. Hasil penelitian menunjukkan bahwa current ratio mempunyai hubungan yang positif dengan perubahan laba yang akan datang tetapi tidak signifikan secara statistik. Dengan adanya hubungan positif antara current ratio dengan perubahan laba diasumsikan bahwa current ratio mampu memprediksi perubahan laba yang akan datang, maka hipotesis yang dapat dirumuskan adalah sebagai berikut: (1) $\mathrm{Ho}_{1}$ : CR tidak mampu memprediksi perubahan laba satu tahun yang akan datang; (2) $\mathrm{Ha}_{1}$ : CR mampu memprediksi perubahan laba satu tahun yang akan datang

\section{Prediksi Perubahan Net Profit Margin (NPM) terhadap Laba}

Net profit margin menunjukkan kemampuan perusahaan dalam menghasilkan pendapatan bersihnya terhadap total penjualan bersihnya. NPM yang semakin besar menunjukkan bahwa semakin besar laba bersih yang diperoleh perusahaan dari kegiatan penjualan. Dengan laba bersih yang besar, bertambah luas kesempatan bagi perusahaan untuk memperbesar modal usahanya tanpa melalui hutang-hutang baru, sehingga pendapatan menjadi meningkat.

Hal ini didukung oleh penelitian Hapsari (2007) yang menguji pengaruh rasio net profit margin terhadap perubahan laba, dan dalam penelitiannya menunjukkan bahwa net profit margin mempunyai pengaruh positif terhadap perubahan laba. Juga dengan penelitian Usman (2003) yang menganalisa rasio keuangan dalam memprediksi perubahan laba pada bank-bank di Indonesia, yang dalam hasil penelitiannya menunjukkan bahwa NPM mempunyai pengaruh yang positif terhadap perubahan laba tetapi tidak signifikan.

Berdasarkan teori dan penelitian sebelumnya yang menunjukkan bukti bahwa net profit margin mempunyai hubungan positif dengan perubahan laba yang akan datang, maka hipotesa yang kedua dapat dirumuskan sebagai berikut: (1) $\mathrm{Ho}_{2}$ : Rasio NPM tidak mampu memprediksi perubahan laba satu tahun yang akan datang; (2) $\mathrm{Ha}_{2}$ : Rasio NPM mampu memprediksi perubahan laba satu tahun yang akan datang.

\section{Prediksi Perubahan Operating Margin Ratio (OMR) terhadap Laba}

Rasio ini mengukur kemampuan perusahaan menghasilkan laba operasi tingkat penjualan tertentu. Nilai rasio yang rendah akan mempunyai pengaruh yang baik terhadap efisiensi perusahaan. Operating Margin Ratio mempunyai pengaruh baik yang dihasilkan perusahaan jika rasio tersebut mempunyai nilai yang rendah, jadi semakin rendah nilai rasio tersebut maka laba yang dihasilkan akan semakin meningkat. Pendapatan atau laba yang bersifat ekstraordiner yang jumlahnya lebih besar dari biaya ekstraordiner juga dapat mempengaruhi besarnya laba bersih yang dihasilkan untuk masa yang akan datang. 
Kemampuan rasio OPM dalam memprediksi perubahan laba yang akan datang telah diteliti oleh Purnawati (2005) dan Ediningsih (2004) yang menguji manfaat rasio Operating Margin Ratio pada perusahaan yang terdaftar di Bursa Efek Indonesia (BEI). Hasil dari penelitian Lina Purnawati menunjukkan bahwa adanya hubungan positif tetapi tidak signifikan secara statistik. Sedangkan hasil penelitian Ediningsih menunjukkan adanya hubungan positif yang signifikan. Berdasarkan teori dua penelitian sebelumnya menunjukkan bukti bahwa OMR berpengaruh positif dalam memprediksi perubahan laba yang akan datang, maka hipotesa alternatif ketiga yang dirumuskan dalam penelitian ini adalah: (1) $\mathrm{Ho}_{3}$ : Rasio OMR tidak mampu memprediksi perubahan laba satu tahun yang akan datang; (2) $\mathrm{Ha}_{3}$ : Rasio OMR mampu memprediksi perubahan laba satu tahun yang akan datang

\section{Prediksi Perubahan Return On Equity (ROE) terhadap Laba}

Rasio return on equity dapat digunakan untuk mengukur profitabilitas dari segi perspektif pemegang saham biasa. Imbalan bagi pemegang saham biasa adalah laba bersih perusahaan. Rasio ini menunjukkan seberapa banyak rupiah yang diperoleh dari laba bersih untuk setiap rupiah yang diinvestasikan oleh para pemegang saham (pemilik perusahaan). Pengaruh rasio return on equity terhadap perubahan laba bersih perusahaan adalah semakin tinggi nilai rasio ini maka semakin tinggi pula tingkat laba yang dihasilkan karena penambahan modal kerja dapat digunakan untuk membiayai operasi perusahaan yang akhirnya dapat menghasilkan laba (Suwarno, 2004).

Juliana \& Sulardi (2003) menguji kemampuan rasio return on equity untuk memprediksi perubahan laba pada perusahaan manufaktur. Hasil penelitian menunjukkan bahwa rasio return on equity mempunyai pengaruh positif tertapi tidak signifikan dalam memprediksi perubahan laba. Berdasarkan penelitian sebelumnya yang membuktikan rasio return on equity mempunya pengaruh positif terhadap perubahan laba yang akan datang, maka hipotesa keempat yang dirumuskan dalam penelitian ini adalah: (1) $\mathrm{Ho}_{4}$ : Rasio ROE tidak mampu memprediksi perubahan laba satu tahun yang akan datang; (2) $\mathrm{Ha}_{4}$ : Rasio ROE mampu memprediksi perubahan laba satu tahun yang akan datang.

\section{Prediksi Perubahan Return On Asset (ROA) terhadap Laba}

Profitability suatu perusahaan dapat diukur dengan menghubungkan antara keuntungan atau laba yang diperoleh dari kegiatan pokok perusahaan dengan kekayaan atau asset yang dimiliki. Rasio ini akan mencerminkan keuntungan yang diperoleh tanpa mengingat dari mana sumber modal dan menunjukkan tingkat efisiensi perusahaan dalam melaksanakan operasi sehari-hari.

Meythi (2005) menguji kemampuan rasio return on asset untuk memprediksi perubahan laba pada perusahaan manufaktur. Hasil penelitian menunjukkan bahwa rasio return on asset mempunyai pengaruh positif dan signifikan dalam memprediksi perubahan laba. Berdasarkan penelitian sebelumnya yang membuktikan rasio return on asset mempunyai pengaruh positif terhadap perubahan laba yang akan datang, maka hipotesa keempat yang dirumuskan dalam penelitian ini adalah: (1) $\mathrm{Ho}_{5}$ : Rasio ROA tidak mampu memprediksi perubahan laba satu tahun yang akan datang; (2) $\mathrm{Ha}_{5}$ : Rasio ROA mampu memprediksi perubahan laba satu tahun yang akan datang

\section{Prediksi Perubahan Total Asset Turnover (TATO) terhadap Laba}

Rasio perputaran total aktiva mengukur aktivitas dan kemampuan perusahaan dalam menghasilkan penjualan melalui penggunaan aktiva tersebut. Rasio ini juga dapat digunakan untuk mengukur seberapa efisien aktiva tersebut telah dimanfaatkan untuk memperoleh penghasilan sehingga rasio ini dapat digunakan untuk memprediksi laba yang akan datang (Hanafi \& Halim, 2003). Rasio ini dapat digunakan untuk memprediksi laba karena total aktiva dan penjualan merupakan komponen dalam menghasilkan laba. 
Pengaruh rasio total asset turnover terhadap perubahan laba bersih perusahaan adalah semakin cepat tingkat perputaran aktivanya maka laba bersih yang dihasilkan akan semakin meningkat, karena perusahaan sudah dapat memanfaatkan aktiva tersebut untuk meningkatkan penjualan yang berpengaruh terhadap pendapatan. Kenaikan pendapatan dapat menaikkan laba bersih perusahaan (Hanafi \& Halim, 2003).

Hapsari (2007) dan Meythi (2005) telah melakukan penelitian yang menguji kemampuan rasio total asset turnover untuk memprediksi perubahan laba. Hasil penelitian menunjukkan bahwa rasio TATO mempunyai kemampuan yang signifikan dalam memprediksi perubahan laba. Berdasarkan penelitian sebelumnya yang sudah membuktikan TATO mampu memprediksi perubahan laba, maka hipotesis keenam yang dirumuskan adalah: (1) $\mathrm{Ho}_{6}$ : Rasio TATO tidak mampu memprediksi perubahan laba satu tahun yang akan datang; (2) $\mathrm{Ha}_{6}$ : Rasio TATO mampu memprediksi perubahan laba satu tahun yang akan datang.

\section{HASIL DAN PEMBAHASAN}

\section{Objek Penelitian}

Objek penelitian ini adalah laporan keuangan perusahaan yang berada di bidang telekomunikasi yang terdaftar di Bursa Efek Indonesia (BEI). Perusahaan telekomunikasi diambil sebagai objek penelitian karena industri tersebut sedang mengalami pertumbuhan yang signifikan pada saat ini. Periode data yang digunakan dalam penelitian ini mulai tahun 2003 sampai dengan 2010.

Tabel 1 Proses pemilihan objek penelitian

\begin{tabular}{lc}
\hline \multicolumn{1}{c}{ Kriteria } & Jumlah \\
\hline 1. Perusahaan telekomunikasi yang terdaftar di BEI sampai & 9 \\
tahun 2010 & \\
2. Perusahaan yang tidak bisa digunakan \\
- Perusahaan yang tidak secara berturut-turut terdaftar \\
$\begin{array}{l}\text { di BEI selama periode } 2003-2010 \\
\text { Perusahaan yang datanya tidak tersedia dan tidak } \\
\text { lengkap }\end{array}$ \\
\hline$\quad$ Total Sampel \\
\hline
\end{tabular}

Berdasarkan hasil seleksi dalam pemilihan objek tersebut, terdapat 4 perusahaan yang dapat dijadikan objek penelitian. Perusahaan tersebut adalah: (1) PT Bakrie Telecom Tbk.; (2) PT Indosat Tbk.; (3) PT Telekomunikasi Indonesia Tbk.; (4) PT XL Axiata Tbk.

\section{Perubahan Rasio Keuangan dan Hasil Pengujian}

Di sini dibahas perubahan rasio keuangan yang telah dianalisa pada masing-masing perusahaan dan rasio keuangan yang telah diteliti. Hal ini dimaksudkan untuk memudahkan dalam membaca dan mengamati tingkat pertumbuhan dari masing-masing perusahaan dan rasio keuangan yang telah diteliti. Selain itu juga menyajikan hasil analisis mengenai kemampuan rasio keuangan dalam memprediksi perubahan laba satu tahun yang akan datang pada perusahaan telekomunikasi yang terdaftar di Bursa Efek Indonesia. Analisis ini dilakukan dengan menggunakan model regresi linear berganda dengan alat bantu statistik SPSS versi 17. Pengujian statistik dilakukan pada tingkat keyakinan 95\% dan tingkat signifikansi 5\% $(\alpha=0,05)$. 


\section{PT Bakrie Telecom Tbk}

Bakrie mengalami penurunan pada tahun 2004, hal itu terlihat dari banyaknya rasio keuangan yang bernilai negative, pada rasio NPM tahun 2004 menunjukkan bahwa menurunnya laba bersih, dan modal yang terlihat dari rasio ROE. Selain itu rasio OMR memiliki nilai rata-rata $0,1 \%$ yang berarti kurang berhasilnya perusahaan dalam kegiatan pokoknya sehingga menghasilkan laba operasi yang minim.

Tabel 2 Perubahan rasio keuangan PT Bakrie Telecom Tbk

\begin{tabular}{lrrrrrrrrr}
\hline & $\mathbf{2 0 0 3}$ & $\mathbf{2 0 0 4}$ & $\mathbf{2 0 0 5}$ & $\mathbf{2 0 0 6}$ & $\mathbf{2 0 0 7}$ & $\mathbf{2 0 0 8}$ & $\mathbf{2 0 0 9}$ & $\mathbf{2 0 1 0}$ & rata-rata \\
\hline CR & 39.0 & 72.0 & 199.0 & 176.0 & 182.0 & 220.0 & 86.0 & 82.0 & 132.0 \\
NPM & 7.0 & -184.0 & -59.0 & 12.0 & 11.0 & 6.0 & 4.0 & 0.0 & -25.4 \\
OMR & 2.0 & -42.0 & -41.0 & 23.0 & 25.0 & 17.0 & 10.0 & 7.0 & 0.1 \\
ROE & 3.0 & -132.0 & -17.0 & 5.0 & 8.0 & 3.0 & 2.0 & 0.0 & -16.0 \\
ROA & 1.0 & -28.0 & -9.0 & 3.0 & 3.0 & 2.0 & 1.0 & 0.0 & -3.4 \\
TATO & 15.2 & 15.4 & 16.0 & 27.4 & 27.7 & 25.8 & 24.0 & 22.4 & 21.7 \\
\hline
\end{tabular}

\section{PT Indosat Tbk}

Pada tahun 2010 Indosat mengalami penurunan di semua rasio. Terlihat pada tahun 2003, Indosat mempunyai $\mathrm{CR}$ sebesar $223 \%$ tetapi pada tahun 2010 hanya $52 \%$ yang berarti semakin berkurangnya kemampuan perusahaan untuk memenuhi kewajiban jangka pendeknya.

Tabel 3 Perubahan rasio keuangan PT Indosat Tbk

\begin{tabular}{lrrrrrrrrr}
\hline & $\mathbf{2 0 0 3}$ & $\mathbf{2 0 0 4}$ & $\mathbf{2 0 0 5}$ & $\mathbf{2 0 0 6}$ & $\mathbf{2 0 0 7}$ & $\mathbf{2 0 0 8}$ & $\mathbf{2 0 0 9}$ & $\mathbf{2 0 1 0}$ & rata-rata \\
\hline CR & 223.0 & 146.0 & 139.0 & 83.0 & 93.0 & 90.0 & 55.0 & 52.0 & 110.1 \\
NPM & 19.0 & 16.0 & 14.0 & 12.0 & 12.0 & 11.0 & 9.0 & 5.0 & 12.3 \\
OMR & 28.0 & 31.0 & 32.0 & 28.0 & 27.0 & 25.0 & 17.0 & 18.0 & 25.8 \\
ROE & 13.0 & 12.0 & 11.0 & 9.0 & 12.0 & 12.0 & 9.0 & 5.0 & 10.4 \\
ROA & 6.0 & 6.0 & 5.0 & 4.0 & 5.0 & 4.0 & 3.0 & 2.0 & 4.4 \\
TATO & 31.5 & 37.4 & 35.4 & 35.8 & 36.4 & 37.1 & 34.0 & 36.8 & 35.5 \\
\hline
\end{tabular}

\section{PT Telekomunikasi Indonesia Tbk}

Telkom mempunyai kinerja yang paling bagus dibandingkan dengan perusahaan telekomunikasi lain, hal tersebut dilihat dari nilai rasio yang tidak pernah negatif dan nilainya relative besar. Telkom mengalami penurunan pada tahun 2008, ditunjukkan oleh menurunnya semua rasio, tetapi masih dapat dikatakan stabil.

Tabel 4 Perubahan Rasio Keuangan PT Telekomunikasi Indonesia Tbk

\begin{tabular}{lccccccccc}
\hline & $\mathbf{2 0 0 3}$ & $\mathbf{2 0 0 4}$ & $\mathbf{2 0 0 5}$ & $\mathbf{2 0 0 6}$ & $\mathbf{2 0 0 7}$ & $\mathbf{2 0 0 8}$ & $\mathbf{2 0 0 9}$ & $\mathbf{2 0 1 0}$ & rata-rata \\
\hline CR & 80.0 & 79.0 & 76.0 & 66.0 & 76.0 & 54.0 & 60.0 & 91.0 & 72.8 \\
NPM & 22.0 & 19.0 & 19.0 & 20.0 & 21.0 & 17.0 & 17.0 & 17.0 & 19.0 \\
OMR & 44.0 & 43.0 & 41.0 & 40.0 & 42.0 & 35.0 & 34.0 & 33.0 & 39.0 \\
ROE & 35.0 & 36.0 & 34.0 & 40.0 & 39.0 & 31.0 & 29.0 & 26.0 & 33.8 \\
ROA & 12.0 & 12.0 & 13.0 & 15.0 & 16.0 & 12.0 & 12.0 & 12.0 & 13.0 \\
TATO & 53.9 & 60.4 & 67.3 & 72.9 & 76.4 & 70.3 & 69.2 & 68.8 & 67.4 \\
\hline
\end{tabular}




\section{PT XL Axiata Tbk}

XL mengalami penurunan pada tahun 2007, hal tersebut dilihat dari menurunnya beberapa rasio, seperti CR yang menurun $10 \%$, NPM sebesar $11 \%$, ROE 9x dan ROA 4x. Tetapi pada tahun 2007, rasio OMR masih cukup bagus, dengan demikian dapat disimpulkan bahwa penyebab menurunnya laba karena biaya-biaya yang tidak berhubungan dengan kegiatan operasional perusahaan.

Tabel 5 Perubahan Rasio Keuangan PT XL Axiata Tbk

\begin{tabular}{lrrrrrrrrr}
\hline & $\mathbf{2 0 0 3}$ & $\mathbf{2 0 0 4}$ & $\mathbf{2 0 0 5}$ & $\mathbf{2 0 0 6}$ & $\mathbf{2 0 0 7}$ & $\mathbf{2 0 0 8}$ & $\mathbf{2 0 0 9}$ & $\mathbf{2 0 1 0}$ & rata-rata \\
\hline CR & 81.0 & 90.0 & 61.0 & 51.0 & 24.0 & 56.0 & 33.0 & 49.0 & 55.6 \\
NPM & 18.0 & -2.0 & -7.0 & 14.0 & 3.0 & 0.0 & 12.0 & 17.0 & 6.9 \\
OMR & 26.0 & 26.0 & 19.0 & 22.0 & 21.0 & 15.0 & 18.0 & 30.0 & 22.1 \\
ROE & 37.0 & -4.0 & -6.0 & 15.0 & 6.0 & 0.0 & 19.0 & 25.0 & 11.5 \\
ROA & 7.0 & -1.0 & -2.0 & 5.0 & 1.0 & 0.0 & 6.0 & 11.0 & 3.4 \\
TATO & 40.4 & 40.0 & 32.7 & 37.1 & 44.5 & 42.5 & 50.1 & 64.1 & 43.9 \\
\hline
\end{tabular}

\section{Perubahan Delta Laba}

Fokus utama laporan keuangan adalah laba. Laba merupakan hasil operasi suatu perusahaan dalam satu periode akuntansi. Informasi ini sangat berguna bagi pemilik, dan investor. Laba yang mengalami peningkatan merupakan kabar baik bagi investor, sedangkan laba yang mengalami penurunan merupakan kabar buruk.

Tabel 6. Perubahan Delta Laba

\begin{tabular}{cccccccccc}
\hline & $\mathbf{2 0 0 3}$ & $\mathbf{2 0 0 4}$ & $\mathbf{2 0 0 5}$ & $\mathbf{2 0 0 6}$ & $\mathbf{2 0 0 7}$ & $\mathbf{2 0 0 8}$ & $\mathbf{2 0 0 9}$ & $\mathbf{2 0 1 0}$ & rata-rata \\
\hline BAKRIE & -0.38 & -27.10 & -0.52 & 1.50 & 0.98 & -0.05 & -0.28 & -0.90 & -3.34 \\
INDOSAT & 3.67 & 0.03 & 0.00 & -0.13 & 0.45 & 0.01 & -0.15 & -0.49 & 0.42 \\
TELKOM & -0.24 & 0.09 & 0.20 & 0.38 & 0.18 & -0.18 & 0.07 & 0.01 & 0.06 \\
XL & -0.47 & -1.12 & -4.42 & 3.91 & -0.62 & -1.06 & 114.14 & 0.69 & 13.88 \\
\hline
\end{tabular}

Berdasarkan Tabel 6, dapat dilihat bahwa XL mempunyai nilai rata-rata perubahan laba paling tinggi yaitu sebesar $13,88 \%$. Sedangkan Bakrie mempunyai nilai rata-rata perubahan laba paling rendah dengan $-3,34 \%$. Terdapat dua perusahaan yang mempunyai perubahan signifikan selama periode penelitian, yaitu Bakrie yang menurun sebesar $-27 \%$ pada tahun 2004, tetapi meningkat kembali pada tahun berikuttnya. Dan XL yang mengalami peningkatan signifikan pada tahun 2009 sebesar $114,14 \%$, tetapi menurun pada tahun berikutnya. Sedangkan perusahaan Indosat dan Telkom tidak mengalami perubahan yang cukup signifikan selama sepuluh tahun ini.

\section{Uji Normalitas}

Statistik deskriptif digunakan untuk melihat tingkat normalitas data yang digunakan untuk penelitian. Tingkat normalitas data dapat dilihat berdasarkan besarnya skewness dan kurtosis. Skewness menunjukkan tingkat kemencengan data, jika jumlahnya semakin besar maka data tersebut semakin menceng, artinya data tidak tersebar dengan rata yang disebabkan oleh data yang ekstrim. Sedangkan kurtosis adalah tingkat kelancipan data, semakin besar kurtosis maka data akan semakin baik. 
Tabel 7 Deskriptif statistik dengan data ekstrim

\begin{tabular}{|c|c|c|c|c|c|c|c|c|c|}
\hline \multicolumn{10}{|c|}{ Descriptive Statistics } \\
\hline & $\mathrm{N}$ & Minimum & Maximum & Mean & Std. Deviation & \multicolumn{2}{|c|}{ Skewness } & \multicolumn{2}{|c|}{ Kurtosis } \\
\hline & Statistic & Statistic & Statistic & Statistic & Statistic & Statistic & Std. Error & Statistic & Std. Error \\
\hline $\mathrm{CR}$ & 32 & 24.00 & 223.00 & 92.6250 & 53.77657 & 1.294 & .414 & .743 & .809 \\
\hline NPM & 32 & -184.00 & 22.00 & 3.1875 & 37.08529 & -4.553 & .414 & 22.427 & .809 \\
\hline OMR & 32 & -42.00 & 44.00 & 21.7500 & 19.51839 & -2.167 & .414 & 5.644 & .809 \\
\hline ROE & 32 & -132.00 & 40.00 & 9.9063 & 29.80405 & -3.565 & .414 & 17.027 & .809 \\
\hline ROA & 32 & -28.00 & 16.00 & 4.3438 & 8.15024 & -1.965 & .414 & 7.209 & .809 \\
\hline TATO & 32 & 15.23 & 76.39 & 42.1416 & 17.99766 & .473 & .414 & -.829 & .809 \\
\hline delta_laba & 32 & -27.10 & 114.14 & 2.8182 & 20.91864 & 5.081 & .414 & 28.254 & .809 \\
\hline Valid N (listwise) & 32 & & & & & & & & \\
\hline
\end{tabular}

Sumber: Data diolah menggunakan SPSS 17

Tabel 7 menunjukkan adanya data ekstrim pada beberapa variabel yang digunakan dalam penelitian. Hal tersebut ditunjukkan dengan adanya beberapa variabel yang memiliki nilai skewness yang cukup besar. Untuk memperoleh tingkat normalitas data yang lebih baik, maka data ekstrim tersebut perlu dihilangkan.

Jumlah data yang digunakan dalam penelitian ini semula berjumlah 32 data, setelah dilakukan eliminasi data ekstrim, jumlah data menjadi 22 dengan data ekstrim yang dihilangkan berjumlah 10 data. Variabel delta laba memiliki data ekstrim positif. Sedangkan variabel NPM, dan ROE mempunyai data ekstrim negatif. Data ekstrim ini perlu dihilangkan karena akan mempengaruhi hasil analisa penelitian.

Tabel 8 Deskriptif Statistik tanpa data ekstrim

\begin{tabular}{|c|c|c|c|c|c|c|c|c|c|}
\hline \multicolumn{10}{|c|}{ Descriptive Statistics } \\
\hline & $\mathrm{N}$ & Minimum & Maximum & Mean & Std. Deviation & \multicolumn{2}{|c|}{ Skewness } & \multicolumn{2}{|c|}{ Kurtosis } \\
\hline & Statistic & Statistic & Statistic & Statistic & Statistic & Statistic & Std. Error & Statistic & Std. Error \\
\hline $\mathrm{CR}$ & 22 & 24.00 & 223.00 & 98.6364 & 56.86286 & 1.105 & .491 & .197 & .953 \\
\hline NPM & 22 & 3.00 & 22.00 & 14.0909 & 5.12612 & -.639 & .491 & -.307 & .953 \\
\hline OMR & 22 & 17.00 & 44.00 & 29.0909 & 8.11177 & .316 & .491 & -.699 & .953 \\
\hline ROE & 22 & 3.00 & 40.00 & 18.7727 & 12.46684 & .434 & .491 & -1.472 & .953 \\
\hline $\mathrm{ROA}$ & 22 & 1.00 & 15.00 & 7.0455 & 4.40213 & .383 & .491 & -1.425 & .953 \\
\hline TATO & 22 & 25.77 & 72.86 & 46.0855 & 16.22296 & .537 & .491 & -1.381 & .953 \\
\hline delta_laba & 22 & -.62 & 3.91 & .4819 & 1.16932 & 2.285 & .491 & 4.863 & .953 \\
\hline $\begin{array}{l}\text { Valid N } \\
\text { (listwise) }\end{array}$ & 22 & & & & & & & & \\
\hline
\end{tabular}

Sumber: Data diolah menggunakan SPSS 17 
Berdasarkan tablediatas terlihat bahwa setelah dilakukan eliminasi data ekstrim, tingkat normalitas data menjadi lebih baik dari data sebelumnya. Hal ini ditunjukkan dengan rendahnya tingkat kemencengan data. Skewness bernilai positif menunjukkan kemencengan data ada pada sisi kanan, sedangkan nilai negatif menunjukkan kemencengan data ada pada sisi kiri. Dari data deskriptif di atas dapat disimpulkan bahwa keseluruhan data yang digunakan dalam penelitian dapat digolongkan sebagai data yang normal. Perbedaan besarnya nilai skewness dan kurtosis masih dapat ditoleransi.

Penentuan suatu variabel terdistribusi normal atau tidak juga dapat dilihat melalui normal probability plot yang penyebaran titik-titik variabelnya seharusnya berada tidak jauh di sekitar garis $\mathrm{Y}=\mathrm{X}$ dan histogram yang membentuk kurva normal (normal curve). Adapun grafik plot penelitian ini terlihat pada gambar berikut ini.

\section{Uji Asumsi Klasik}

Sebelum dilakukan analisis regresi maka perlu dilakukan pengujian asumsi klasik terlebih dahulu agar model yang digunakan dapat menunjukkan hubungan yang akurat. Adapun uji asumsi kasik yang akan dipakai dalam penelitian ini adalah uji autokorelasi, uji multikolinearitas, dan uji heteroskedasitas.

\section{Uji Autokorelasi}

Autokorelasi menunjukkan adanya korelasi antara kesalahan pengganggu pada periode $t$ dengan kesalahan pada periode t-1. Konsekuensinya, variasi sampel tidak dapat menggambarkan variasi populasinya. Akibat yang lebih jauh lagi, model regresi yang dihasilkan tidak dapat digunakan untuk menaksir nilai variabel dari variabel independennya. Untuk mengetahui adanya autokorelasi dalam suatu model regresi, dilakukan pengujian Durbin-Watson (DW).

Pada data penelitian ini, didapatkan nilai DW 1,972 seperti terlihat pada Tabel 9.

Tabel 9 Hasil Uji Autokorelasi

\begin{tabular}{|c|c|c|c|c|c|}
\hline Model & $\mathrm{R}$ & R Square & Adjusted R Square & $\begin{array}{c}\text { Std. Error of the } \\
\text { Estimate }\end{array}$ & Durbin-Watson \\
\hline 1 & $.739^{\mathrm{a}}$ & .546 & .364 & .93272 & 2.027 \\
\hline
\end{tabular}

a. Predictors: (Constant), TATO, CR, NPM, OMR, ROE, ROA

b. Dependent Variable: delta_laba

Sumber: Data diolah menggunakan SPSS 17

Berdasarkan hasil perhitungan pada penelitian ini, nilai DW berada diantara 1,55 sampai dengan 2,46, sehingga dapat disimpulkan bahwa tidak terdapat autokorelasi pada persamaan regresi penelitian ini.

\section{Uji Multikolinearitas}

Uji multikolinearitas dimaksudkan untuk mengetahui apakah terdapat interkorelasi sempurna antara variabel-variabel independen yang digunakan dalam penelitian ini. Uji ini dilakukan dengan Tolerance Value dan Variance Inflation Factor (VIF). Agar tidak terjadi multikolinearitas, batas Tolerance Value $>0,1$ dan VIF $<10$. Adapun hasil uji multikolinearitas pada penelitian ini dapat dilihat pada tabel berikut. 
Tabel 10. Hasil Uji Multikolinearitas

\begin{tabular}{|c|c|c|c|}
\hline \multicolumn{4}{|c|}{ Coefficients $^{\mathrm{a}}$} \\
\hline \multirow{2}{*}{\multicolumn{2}{|c|}{ Model }} & \multicolumn{2}{|c|}{ Collinearity Statistics } \\
\hline & & Tolerance & VIF \\
\hline \multirow[t]{7}{*}{1} & (Constant) & & \\
\hline & $\mathrm{CR}$ & .314 & 3.186 \\
\hline & NPM & .168 & 4.643 \\
\hline & OMR & .191 & 5.244 \\
\hline & ROE & .106 & 9.454 \\
\hline & ROA & .413 & 7.243 \\
\hline & TATO & .272 & 3.781 \\
\hline
\end{tabular}

Berdasarkan Tabel 10, nilai tolerance value $>0,1$ dan VIF $<10$, sehingga dapat disimpulkan bahwa keenam variabel independen tersebut tidak terdapat hubungan multikolinearitas dan dapat digunakan untuk memprediksi pertumbuhan laba untuk satu tahun yang akan datang.

\section{Uji Heteroskedasitas}

Pengujian ini bertujuan untuk menguji apakah terjadi ketidaksamaan varian dan redual satu pengamatan ke pengamatan lain dalam model regresi. Model penelitian yang baik adalah homoskeditas, yaitu varian dan redual satu pengamatan ke pengamatan lainnya tetap. Terdapat beberapa cara untuk mendeteksi adanya heteroskeditas yang menunjukkan bahwa model penelitian kurang layak. Dalam penelitian ini digunakan diagram titik (scatter plot) yang seharusnya titik-titik tersebut tersebar acak agar tidak terdapat heteroskeditas. Adapun hasil uji heteroskeditas dalam penelitian ini disajikan pada gambar berikut.

\section{Analisis Regresi Linear Berganda}

Dari pengujian normalitas data dan asumsi klasik, dapat disimpulkan bahwa data yang terdistribusi normal, tidak terdapat multikolinearitas dan heteroskedasitas sehingga memenuhi persyaratan untuk melakukan analisis regresi linear berganda. Pengujian hipotesis ini menggunakan nilai koefisien determinasi $\left(\mathrm{R}^{2}\right)$, uji $\mathrm{F}$, dan uji t.

\section{Koefisien Determinasi $\left(\mathbf{R}^{2}\right)$}

Koefisien determinasi $\left(\mathrm{R}^{2}\right)$ pada intinya mengukur seberapa jauh kemampuan model dalam menerangkan variabel dependen. Nilai $R^{2}$ yang kecil berarti kemampuan variabel-variabel independen dalam menjelaskan variabel dependennya terbatas. Sebaliknya, nilai $\mathrm{R}^{2}$ yang mendekati satu menandakan variabel-variabel independen memberikan hamper semua informasi yang dibutuhkan oleh variabel dependen (Ghozali, 2005).

Nilai yang digunakan adalah adjusted $\mathrm{R}^{2}$ karena variabel independen yang digunakan dalam penelitian ini lebih dari dua buah. Adapun nilai adjusted $\mathrm{R}^{2}$ dari hasil perhitungan terlihat pada Tabel 11. 
Tabel 11. Nilai $\mathrm{R}^{2}$

\begin{tabular}{|c|c|c|c|c|}
\hline \multicolumn{5}{|c|}{ Model Summary } \\
\hline Model & $\mathrm{R}$ & R Square & Adjusted R Square & $\begin{array}{l}\text { Std. Error of the } \\
\text { Estimate }\end{array}$ \\
\hline 1 & $.739^{\mathrm{a}}$ & .546 & .364 & .93272 \\
\hline
\end{tabular}

Dari hasil perhitungan diperoleh hasil besarnya pengaruh variabel independen terhadap variabel dependen yang dapat diterangkan oleh model persamaan ini sebesar $36,4 \%$, dan sisanya $63,6 \%$ dipengaruhi oleh faktor-faktor lain yang tidak dimasukkan dalam model regresi.

\section{Uji Statistik F}

Pengujian ini dimaksudkan untuk mengetahui pengaruh antara variabel independen dan variabel dependen secara bersama-sama (simultan). Berdasarkan hasil analisis regresi dapat diketahui bahwa keenam variabel independen secara bersama-sama berpengaruh signifikan terhadap pertumbuhan laba. Hal ini dapat dilihat dari nilai $\mathrm{F}$ sebesar 0,039 yang lebih kecil dari tingkat signifikasinya yaitu sebesar 0,05 seperti yang ditunjukkan pada Tabel 12 .

Tabel 12. Hasil Uji F

\begin{tabular}{|ll|r|r|r|r|r|}
\hline Model & & Sum of Squares & df & Mean Square & F & \multicolumn{1}{c|}{ Sig. } \\
\hline 1 & Regression & 15.664 & 6 & 2.611 & 3.001 & $.039^{\text {a }}$ \\
& Residual & 13.050 & 15 & .870 & & \\
& Total & 28.714 & 21 & & & \\
\hline
\end{tabular}

a. Predictors: (Constant), TATO, CR, NPM, OMR, ROE, ROA

b. Dependent Variable: delta_laba

Sumber : Data diolah menggunakan SPSS 17

\section{Uji Statistik t}

Pengujian ini bertujuan untuk mengetahui ada atau tidaknya pengaruh satu variabel independen terhadap variabel dependen secara parsial dengan menganggap variabel independen lain konstan. Pengujian ini dilakukan dengan membandingkan nilai signifikansi t yang ditunjukkan oleh Sig dari $\mathrm{t}$ pada tabel 4.18 dengan tingkat signifikasi yang diambil adalah 0,05 . Jika nilai sig dari $\mathrm{t}<$ 0,05 maka variabel independen berpengaruh terhadap variabel dependen. 
Tabel 13. Hasil Uji t

\begin{tabular}{|c|c|c|c|c|c|c|}
\hline \multicolumn{7}{|c|}{ Coefficients ${ }^{\mathrm{a}}$} \\
\hline \multirow{2}{*}{\multicolumn{2}{|c|}{ Model }} & \multicolumn{2}{|c|}{ Unstandardized Coefficients } & \multirow{2}{*}{$\begin{array}{c}\begin{array}{c}\text { Standardized } \\
\text { Coefficients }\end{array} \\
\text { Beta }\end{array}$} & \multirow[b]{2}{*}{$\mathrm{t}$} & \multirow[b]{2}{*}{ Sig. } \\
\hline & & $\mathrm{B}$ & Std. Error & & & \\
\hline 1 & (Constant) & -.133 & 3.256 & & -.041 & .968 \\
\hline & $\mathrm{CR}$ & .000 & .006 & .017 & .056 & .956 \\
\hline & NPM & .378 & .152 & 1.657 & 2.488 & .025 \\
\hline & OMR & -.134 & .057 & -.929 & -2.330 & .034 \\
\hline & ROE & -.052 & .050 & -.551 & -1.029 & .320 \\
\hline & ROA & -.109 & .412 & -.410 & -.265 & .795 \\
\hline & TATO & .019 & .076 & .266 & .252 & .804 \\
\hline
\end{tabular}

Dari tabel 13, dapat ditulis persamaan regresi linear sebagai berikut:

\section{$\Delta$ LABA $=-0,133+0,00$ CR + 0,378 NPM $-0,134$ OMR - 0,052 ROE $-0,109$ ROA + 0,019 TATO $+\mathbf{e}$}

Berdasarkan hasil perhitungan, dapat dilihat bahwa terdapat dua variabel independen yaitu variabel NPM dan OMR yang berpengaruh signifikan terhadap variabel dependen yaitu perubahan laba, dengan tingkat signifikasi masing-masing sebesar 0,025 dan 0,034. Sedangkan variabel CR, ROE, ROA dan TATO tidak memiliki pengaruh yang signifikan terhadap perubahan laba. Hal ini dikarenakan nilai sig t untuk variabel CR, ROE, ROA dan TATO masing-masing sebesar 0,956; 0,$320 ; 0,795$; dan 0,804 yang lebih besar dari tingkat signifikansinya yaitu sebesar 0,05 .

\section{Pengujian Hipotesis}

\section{Hipotesis $1\left(\mathrm{Ha}_{1}\right)$}

Hipotesis pertama yang diajukan pada penelitian ini adalah Current Ratio (CR) mampu memprediksi perubahan laba yang akan datang. Dalam penelitian ini diperoleh nilai koefisien regresi sebesar 0 dengan tingkat signifikasi sebesar 0,956 , di mana nilai ini tidak signifikan pada tingkat signifikansi 0,05 karena lebih besar dari 0,05. Dengan demikian hipotesis pertama yang menyatakan bahwa Current Ratio mampu memprediksi perubahan laba satu tahun yang akan datang tidak dapat diterima.

Ketidakmampuan current ratio dalam memprediksi perubahan laba sangat dimungkinkan karena dalam current ratio terkandung current asset dan current liabilities yang belum tentu menghasilkan laba. Dalam current ratio, hasil penjualan, laba dan perubahan-perubahan kondisi operasi perusahaan tidak dipertimbangkan sehingga kurang mencerminkan laba yang direalisasikan di masa yang akan datang.

Current ratio menunjukkan hanya mempunyai sedikit sekali hubungan bahkan hampir tidak ada dengan perubahan laba yang akan datang, tetapi tidak signifikan secara statistik, yang berarti setiap kenaikan current ratio tidak akan menaikkan perubahan laba walaupun tidak signifikan. Hasil penelitian ini konsisten dengan penelitian yang dilakukan oleh Roma Uly Juliana \& Sulardi (2003) dan 
Lina Purnawati (2005) yang menyatakan bahwa current ratio mempunyai hubungan positif tetapi tidak signifikan dengan perubahan laba.

\section{Hipotesis $2\left(\mathrm{Ha}_{2}\right)$}

Hipotesis kedua yang diajukan pada penelitian ini adalah rasio Net Profit Margin (NPM) mampu memprediksi perubahan laba satu tahun yang akan datang. Dari hasil penelitian ini diperoleh nilai koefisien regresi untuk variabel NPM adalah sebesar 0,378 dengan nilai signifikansi sebesar 0,025 , dimana nilai ini signifikan pada tingkat signifikansi 0,05 karena lebih kecil dari 0,05 . Dengan demikian maka hipotesis kedua yang menyatakan bahwa NPM mampu memprediksi perubahan laba satu tahun yang akan datang dapat diterima.

Kemampuan NPM dalam memprediksi perubahan laba sangat dimungkinkan karena rasio ini berhubungan dengan efisiensi perusahaan dalam memproduksi, administrasi, pemasaran, dan pendanaan sehingga rasio ini layak untuk dijadikan prediktor laba. Berdasarkan data empiris yang ada dan dari hasil penelitian yang diperoleh, mengindikasikan bahwa proporsi naik dan turunnya variabel NPM dapat memprediksi perubahan laba satu tahun yang akan datang. Net profit margin mempunyai hubungan yang positif dan signifikan dengan perubahan laba, hal ini berarti setiap kenaikan NPM dapat menaikkan perubahan laba tetapi secara signifikan. Hasil penelitian ini konsisten dengan penelitian yang dilakukan oleh Hapsari (2007) yang menyatakan bahwa net profit margin mempunyai hubungan positif dan signifikan dengan perubahan laba.

\section{Hipotesis $3\left(\mathrm{Ha}_{3}\right)$}

Hipotesis ketiga yang diajukan pada penelitian ini adalah rasio Operating Margin Ratio (OMR) mampu memprediksi perubahan laba satu tahun yang akan datang. Dari hasil penelitian ini diperoleh nilai koefisien regresi untuk variabel OMR adalah sebesar -0,134 dengan nilai signifikansi sebesar 0,034, dimana nilai ini signifikan pada tingkat signifikansi 0,05 . Dengan demikian maka hipotesis ketiga yang menyatakan bahwa OMR mampu memprediksi perubahan laba satu tahun yang akan datang dapat diterima.

Berdasarkan data empiris yang ada dan dari hasil penelitian yang diperoleh, mengindikasikan bahwa proporsi naik dan turunnya variabel OMR dapat memprediksi perubahan laba satu tahun yang akan datang. Operating Margin Ratio mempunyai hubungan yang negatif tetapi signifikan dengan perubahan laba, hal ini berarti setiap kenaikan OPM dapat menurunkan perubahan laba secara signifikan. Hasil penelitian ini tidak konsisten dengan penelitian yang dilakukan oleh Ediningsih (2004) yang menyatakan bahwa rasio OMR dapat berpengaruh secara signifikan untuk memprediksi perubahan laba.

\section{Hipotesis $4\left(\mathrm{Ha}_{4}\right)$}

Hipotesis keempat yang diajukan pada penelitian ini adalah rasio Return On Equity (ROE) mampu memprediksi perubahan laba satu tahun yang akan datang. Dari hasil penelitian ini diperoleh nilai koefisien regresi untuk variabel ROE adalah sebesar -0.052 dengan nilai signifikansi sebesar 0,320 , dimana nilai ini tidak signifikan pada tingkat signifikansi 0,05. Dengan demikian maka hipotesis keempat yang menyatakan bahwa ROE mampu memprediksi perubahan laba satu tahun yang akan datang tidak dapat diterima.

Berdasarkan data empiris yang ada dan dari hasil penelitian yang diperoleh, mengindikasikan bahwa proporsi naik dan turunnya variabel ROE tidak dapat memprediksi perubahan laba satu tahun yang akan datang. Return On Equity mempunyai hubungan yang negatif dan tidak signifikan dengan perubahan laba, hal ini berarti setiap kenaikan ROE dapat menurunkan perubahan laba tetapi tidak signifikan. 
Ketidakmampuan ROE dalam memprediksi perubahan laba sangat dimungkinkan karena sifat dan pola investasi yang dilakukan oleh perusahaan kurang tepat sehingga ada sebagian aktiva yang menganggur dan tidak dapat digunakan secara efisien, sehingga laba yang diperoleh tidak maksimal. Selain itu pendapatan yang dihasilkan oleh modal yang berasal dari hutang tidak dapat digunakan untuk menutup besarnya biaya modal dan kekurangan tersebut sehingga harus ditutup oleh sebagian pendapatan yang berasal dari pemegang saham.

Hasil penelitian ini tidak sejalan dengan penelitian yang dilakukan oleh Juliana \& Sulardi (2003) dan Purnawati (2005) yang menyatakan bahwa return on equity mempunyai hubungan positif tetapi tidak signifikan dengan perubahan laba.

\section{Hipotesis $5\left(\mathrm{Ha}_{5}\right)$}

Hipotesis kelima yang diajukan pada penelitian ini adalah rasio Return On Asset (ROA) mampu memprediksi perubahan laba satu tahun yang akan datang. Dari hasil penelitian ini diperoleh nilai koefisien regresi untuk variabel ROA adalah sebesar -0,109 dengan nilai signifikansi sebesar 0,795, dimana nilai ini tidak signifikan pada tingkat signifikansi 0,05 . Dengan demikian maka hipotesis kelima yang menyatakan bahwa ROA mampu memprediksi perubahan laba satu tahun yang akan datang tidak dapat diterima.

Berdasarkan data empiris yang ada dan dari hasil penelitian yang diperoleh, mengindikasikan bahwa proporsi naik dan turunnya variabel ROA tidak dapat memprediksi perubahan laba satu tahun yang akan datang. Return on Asset mempunyai hubungan yang negatif dan tidak signifikan dengan perubahan laba, hal ini berarti setiap kenaikan ROA dapat menurunkan perubahan laba tetapi tidak signifikan.

Ketidakmampuan RoA dalam memprediksi perubahan laba sangat dimungkinkan karena terdapat asset yang tidak digunakan untuk proses produksi, sehingga walaupun jumlah asset yang besar tetapi tidak dapat digunakan secara maksimal untuk menambah laba perusahaan. Hasil penelitian ini tidak sejalan dengan penelitian yang dilakukan oleh Meythi (2005) yang menyatakan bahwa return on asset mempunyai hubungan positif dan signifikan dengan perubahan laba.

\section{Hipotesis $6\left(\mathrm{Ha}_{6}\right)$}

Hipotesis keenam yang diajukan pada penelitian ini adalah rasio Total Asset Turnover (TATO) mampu memprediksi perubahan laba satu tahun yang akan datang. Dari hasil penelitian ini diperoleh nilai koefisien regresi untuk variabel TATO adalah sebesar 0,019 dengan nilai signifikansi sebesar 0,804, dimana nilai ini tidak signifikan pada tingkat signifikansi 0,05. Dengan demikian maka hipotesis keenam yang menyatakan bahwa TATO mampu memprediksi perubahan laba satu tahun yang akan datang tidak dapat diterima.

Berdasarkan data empiris yang ada dan dari hasil penelitian yang diperoleh, mengindikasikan bahwa proporsi naik dan turunnya variabel TATO tidak dapat memprediksi perubahan laba satu tahun yang akan datang. Total asset turnover mempunyai hubungan yang positif tetapi tidak signifikan dengan perubahan laba, hal ini berarti setiap kenaikan TATO dapat menaikkan perubahan laba tetapi tidak secara signifikan.

Hasil penelitian ini tidak konsisten dengan penelitian yang dilakukan oleh Hapsari (2007) yang menyatakan bahwa total asset turnover mempunyai hubungan positif dan signifikan dengan perubahan laba. Tetapi sejalan dengan penelitian Meythi (2005) yang menyatakan bahwa total asset turnover mempunyai hubungan positif tetapi tidak signifikan dengan perubahan laba. 


\section{PENUTUP}

Dari hasil penelitian ini membuktikan bahwa tidak semua rasio keuangan yang diajukan berpengaruh signifikan terhadap perubahan laba. Dari data yang ada, diperoleh hasil bahwa CR mempunyai nilai positif tetapi tidak terhadap perubahan laba. Hasil penelitian ini konsisten dengan penelitian yang dilakukan oleh Juliana \& Sulardi (2003) dan Purnawati (2005) yang menyatakan bahwa current ratio mempunyai hubungan positif tetapi tidak signifikan dengan perubahan laba.

Hasil penelitian ini menyatakan bahwa NPM mempunyai hubungan yang positif dan signifikan dengan perubahan laba. Hal ini konsisten dengan penelitian yang dilakukan oleh Hapsari (2007) yang menyatakan bahwa net profit margin mempunyai hubungan positif dan signifikan dengan perubahan laba. Dari hasil temuan yang ada diperoleh hasil bahwa OMR mempunyai hubungan yang negatif tetapi signifikan dengan perubahan laba. Hal ini tidak sejalan dengan penelitian yang dilakukan oleh Ediningsih (2004) yang menyatakan bahwa OMR mempunyai hubungan yang positif dan signifikan dengan perubahan laba.

Penelitian ini menemukan bahwa ROE mempunyai hubungan yang negatif dan tidak signifikan dengan perubahan laba. Hasil penelitian ini tidak sejalan dengan penelitian yang dilakukan oleh Roma Uly Juliana \& Sulardi (2003) dan Lina Purnawati (2005) yang menyatakan bahwa return on equity mempunyai hubungan positif tetapi tidak signifikan dengan perubahan laba.

Dalam penelitian ini, menunjukkan bahwa ROA mempunyai hubungan yang negatif dan tidak signifikan dengan perubahan laba. Hal ini tidak sejalan dengan penelitian yang dilakukan oleh Meythi (2005) yang menyatakan bahwa ROA mempunyai hubungan yang positif dan signifikan dalam memprediksi perubahan laba.

Hasil penelitian ini menyatakan bahwa TATO mempunyai hubungan yang positif tetapi tidak signifikan dengan perubahan laba. Hal ini sejalan dengan penelitian yang dilakukan oleh Meythi (2005) yang menyatakan bahwa total asset turnover mempunyai hubungan positif tetapi tidak signifikan dengan perubahan laba.

\section{Simpulan}

Berdasarkan hasil analisa data dan pembahasan yang telah dilakukan, maka dapat disimpulkan hal-hal sebagai berikut. Enam rasio keuangan yang digunakan dalam penelitian periode 2003-2010 secara bersama-sama memiliki nilai sebesar $36,4 \%$ sesuai dengan yang tercatat pada nilai adjusted $R^{2}$. Artinya masih terdapat $63.6 \%$ variabel-variabel independen lain yang belum diketahui dan diteliti secara ilmiah untuk memprediksi perubahan laba. Hal ini dikarenakan penelitian ini hanya memperhatikan faktor fundamental perusahaan tanpa memperhatikan kondisi ekonomi makro yang mungkin bisa berpengaruh terhadap perubahan laba.

Dari keenam variabel (CR, NPM, OMR, ROE, ROA dan TATO) yang diduga berpengaruh terhadap perubahan laba, ternyata hanya ada dua variabel yang berpengaruh signifikan terhadap perubahan laba. Kedua variabel tersebut adalah NPM dan OMR sedangkan empat variabel lainnya yaitu CR, ROE, ROA dan TATO terbukti tidak signifikan mempengaruhi perubahan laba.

Dari hasil uji F, terbukti bahwa nilai signifikansi $\mathrm{F}$ lebih kecil dari nilai signifikansi yang telah ditentukan sebelumnya, yaitu 0,039. Artinya seluruh variabel independen dalam penelitian ini secara bersama-sama berpengaruh signifikan terhadap perubahan laba sebagai variabel dependen. 
Dari hasil uji $\mathrm{t}$, dengan melihat nilai signifikansi, variabel yang paling signifikan terhadap perubahan laba adalah NPM dengan nilai signifikansi t sebesar 0,025 dan variabel independen yang paling tidak berpengaruh terhadap perubahan laba adalah CR dengan nilai signifikansi t sebesar 0,956.

\section{Keterbatasan}

Dalam melakukan penelitian, terdapat beberapa keterbatasan yang dapat mempengaruhi hasil analisis, keterbatasan itu di antaranya adalah: (1) data outliers berupa nilai ekstrim pada penelitian ini tidak seluruhnya dihilangkan, karena jika dihilangkan seluruhnya maka data yang digunakan akan semakin sedikit; (2) tidak dimasukkannya faktor ekonomi makro dalam model regresi, sehingga model regresi hanya mempunyai hasil $36,4 \%$, sedangkan $63,6 \%$ sisanya dipengaruhi oleh faktor-faktor lain.

\section{DAFTAR PUSTAKA}

Ediningsih, S. I. (2004). Rasio keuangan dan prediksi pertumbuhan laba: Studi empiris pada perusahaan manufaktur di BEJ. Wahana, Vol. 7, No. 1.

Ghozali, I. (2005). Aplikasi Analisis Multivariate dengan Program SPSS. Badan Penerbit Universitas Diponegoro.

Hanafi, M. M., \& Halim, A. (2000). Analisis laporan keuangan. UPP AMP YKPN.

Hapsari, E. A. (2007). Analisis rasio keuangan untuk memprediksi pertumbuhan laba. Semarang: Universitas Diponegoro.

Ikatan Akuntan Indonesia (IAI). (2009). Standar akuntansi keuangan. Jakarta: Salemba Empat.

Juliana, R. U., \& Sulardi. (2003). Manfaat rasio keuangan dalam memprediksi perubahan laba perusahaan manufaktur. Jurnal Bisnis \& Manajemen, Vol. 3, No.2.

Meythi. (2005). Rasio keuangan yang paling baik untuk memprediksi pertumbuhan laba: Suatu studi empiris pada perusahaan manufaktur yang terdaftar di Bursa Efek Jakarta. Jurnal Ekonomi dan Bisnis Vol. XI No. 2, September.

Purnawati, L. (2005). Kemampuan rasio keuangan dalam memprediksi perubahan laba. Yogyakarta.

Suwarno, A. E. (2004). Manfaat informasi rasio keuangan dalam memprediksi perubahan laba: Studi empiris terhadap perusahaan manufaktur go publik di Bursa Efek Jakarta. Jurnal Akuntansi dan Keuangan, Vol. 3, No. 2.

\section{RIWAYAT PENULIS}

Engelwati Gani lahir di Padang, 07 Januari 1959. Menamatkan S1 di Universitas Andalas bidang akuntansi tahun 1987 dan S2 di Universitas Bina Nusantara tahun 2002 bidang Sistem Informasi Akuntansi. Saat ini bekerja sebagai dosen di Universitas Bina Nusantara dan STMIK Jibes, Finance \& Accounting Manager di PT Pratindo CanggihMulia. 